\title{
Paternity and status in a rhesus monkey group
}

\author{
Susan W. Duvall, I. S. Bernstein* $\uparrow$ and T. P. Gordon $\dagger$ \\ Departments of Zoology and *Psychology, University of Georgia, Athens, Georgia 30602, \\ and $†$ Yerkes Regional Primate Research Center, Emory University, Atlanta, Georgia, U.S.A.
}

\begin{abstract}
Summary. In the blood from 63 rhesus monkeys (Macaca mulatta), transferrin, 6-phosphogluconate dehydrogenase, carbonic anhydrase II, phosphohexose isomerase, NADH diaphorase and leucocyte antigens were polymorphic.

On the basis of these traits, paternity eliminations were determined for 29 offspring of 26 females from an established breeding group containing 8 sexually mature males. The dominance of the males was assessed by the directionality of the agonistic encounters. After examination of the results for two breeding seasons it was found that (1) the alpha male did not do all, or even most, of the successful mating and (2) there was evidence demonstrating increased reproductive success for males as a function of relative agonistic rank for the second but not the first of the 2 years.
\end{abstract}

\section{Introduction}

An important characteristic of macaque and baboon societies is the presence of dominance hierarchies. The prevalence and consistency of this social mechanism strongly suggests that it developed in response to powerful selective pressures. Goss-Custard, Dunbar \& Aldrich-Blake (1972) suggest that such selection could be sexual, e.g. high-ranking males would have greater access to receptive females and therefore higher genetic fitness than low-ranking males. Since genetic fitness of an individual is determined by his relative contribution of genetic material to the next generation's gene pool, genetic fitness would be measured by the relative number of offspring surviving to reproduce.

There are three theoretically important possibilities concerning the relationship of rank to male reproduction: (1) all of the infants born into a troop are the offspring of the highest ranking male, (2) the number of offspring produced by a male is a function of his rank in the troop, or (3) the number of offspring produced by a male is independent of his rank. If either the first or second of these hypotheses were true, high-ranking males would have higher genetic fitness by fathering a greater proportion of infants and, in this way, perpetuate their own genetic characteristics, including those attributes which contributed to their dominant status. If the third hypothesis proves correct, then dominant males do not have increased genetic fitness due to increased reproductive activity, but may achieve higher genetic fitness through some other mechanism.

There are some data for rhesus monkeys which suggest that there is a positive correlation between a male's rank in a troop and the amount of mating behaviour in which he engages (Carpenter, 1942; Conaway \& Koford, 1965; Koford, 1963; Kaufman, 1965, 1967; Sade, 1968). Koford (1963) reported that among the rhesus monkeys of Cayo Santiago, the top fifth of the males performed four-fifths of the copulations that were observed. Kaufmann (1965) found that the highest-ranking male was by far the most sexually active, and Hall \& DeVore (1965) have reported similar data for baboons.

This evidence for greater sexual activity by dominant males has not gone unchallenged (Eaton \& Resko, 1974; Gartlan, 1968; Loy, 1971 ; Simonds, 1974). One possible explanation for these contradictory findings is suggested by Drickamer (1974) who found that all males in the rhesus colony at La Parguera were not equally visible; high-ranking males wers more conspicuous than low-ranking males. When observability was considered Drickamer could not show that high-ranking males engaged in more sexual activity than did low-ranking males.

Nevertheless, it may still be argued that even if the total mounts for all males are equal, the dominant males might still have preferential access to females at ovulation. Laboratory studies have 
demonstrated a pheromonal mechanism operating in rhesus monkeys whereby males might detect the time of ovulation in females (Keverne \& Michael, 1971) and high-ranking males could therefore father all, or most, of the offspring.

Since it is not feasible, even in a captive social group, to record all sexual behaviour, and to determine the precise reproductive state of all females, these hypotheses can best be tested by determining the paternity of infants produced in a multi-male group.

\section{Materials and Methods}

\section{Animals}

Rhesus monkeys housed at the Yerkes Regional Primate Research Center Field Station were selected as subjects. The group was established in 1970 and by the time of testing (1973) consisted of 98 animals including 8 sexually mature males and 39 parous females. Twenty-nine infants born during 1972 and 1973 were selected as the test population. These were the offspring of 26 females.

Dominance was defined by the directionality of agonistic encounters (Bernstein, 1970) and rank hierarchies within this group for the 1971 and 1972 breeding seasons were ascertained. Breeding in this colony has been limited to the period October-February with the majority of infants born in April and May (Gordon, Rose \& Bernstein, 1976).

Paternity was tested by analysis of serum proteins, red cell enzymes and leucocyte antigens. A blood sample from each of the subjects was collected by venepuncture into vacutainers containing heparin. The blood was centrifuged and the plasma removed. Leucocytes were separated with ficoll-isopaque. Haemolysates were prepared by washing the red cells three times in saline, lysing with two volumes of distilled water and centrifuging at $27,000 \mathrm{~g}$ for $15 \mathrm{~min}$ to remove stroma. Antigen typing was carried out within $10 \mathrm{hr}$ and analysis of serum proteins and red cell enzymes within $72 \mathrm{hr}$ of the blood sample being taken.

\section{Analyses}

Plasma was examined by horizontal starch gel electrophoresis using the buffer system of Poulik (1957). Gels were run at $50 \mathrm{~mA}$ until the borate line had migrated to the cathode. Gels were sliced horizontally and a cut surface stained. The protein stain Coomassie blue was used to determine transferrin type. When plasma was examined for haptoglobin, $\mathbf{0 . 0 5} \mathrm{ml}$ haemoglobin solution was added to $1 \mathrm{ml}$ plasma before running. The gel slice was stained for haptoglobin with benzidine reagent (Smithies, 1959).

Haemolysates were examined by acrylamide and starch gel (Electrostarch No. 371) electrophoresis. Horizontal $6 \%$ acrylamide gel slabs, $\mathrm{pH} 7 \cdot 5$, were run at $90 \mathrm{~mA}$ for $4 \mathrm{hr}$ using tris-citrate electrode buffer, pH 7.5, sliced and stained by the method of Barnicot \& Hewett-Emmitt (1971) for lactate dehydrogenase (LDH); Giblett (1969) for malate dehydrogenase (MDH); Barnicot \& Cohen (1970) for glucose 6-phosphate dehydrogenase (G6PD); Fildes \& Parr (1963) for 6-phosphogluconate dehydrogenase (6PGD); Ishimoto \& Kuwata (1972) for phosphohexose isomerase (PHI); and Fildes \& Harris (1966) for adenylate kinase (AK). Horizontal tris-malate-EDTA starch gels were run for $18 \mathrm{hr}$ at $75 \mathrm{~mA}$ and stained for phosphoglucomutase (PGM) (Spencer et al., 1964). Vertical borate sodium hydroxide starch gels were run for $5 \mathrm{hr}$ at $50 \mathrm{~mA}$ and stained for carbonic anhydrase I (CA I) and carbonic anhydrase II (CA II) (Tashian, 1965; Tashian et al., 1971). Horizontal trisEDTA-borate starch gels were run for $4 \mathrm{hr}$ at $50 \mathrm{~mA}$ and stained for NADH diaphorase (Ishimoto, 1971). Leucocyte antigen types were determined by a microcytotoxicity test (B. Amos, personal communication) with antisera obtained from Dr H. Balner. The tests for serum proteins and red cell enzymes, with the exception of NADH diaphorase, were performed on all samples. NADH diaphorase and leucocyte antigens were assessed only for the males, except for $\mathrm{Kd}$ who died before the leucocyte antigens could be tested, and those infants, and when necessary their mothers, for whom paternity had not been established by previous tests. 


\section{Results}

The enzymes LDH, MDH, G6PD, AK, PGM, CA I and haptoglobin did not appear to be polymorphic. Transferrin, 6PGD, PHI, CA II, NADH diaphorase and leucoctye antigens were polymorphic in this population. Eight alleles were found for transferrin, and were designated as A, B, C, D, E, F, G and H. Two alleles, designated as A and B (Prochodko et al., 1972), were present for 6PGD, two alleles, 1 and 9 (Ishimoto \& Kuwata, 1972), were present for PHI, and two alleles, A and B (Tashian, 1965), were present for CA II. Three alleles were present for NADH diaphorase; two, $\mathrm{C}$ and $\mathrm{D}$, have been reported by Ishimoto (1971) for rhesus monkeys. One monkey (Oa) had an additional unreported allele which was designated $E$. There are two loci for leucocyte antigens. At the first locus are the alleles designated as $6,9,10,5^{*}, R_{1}, R_{3}$ and $r 19$ and at the second locus are 13 , $11^{*}, 2^{*}, 14, \mathrm{r17}, \mathrm{r} 18$ and $\mathrm{r} 20$ (H. Balner, personal communication). The results of the examinations of the six polymorphic enzymes of the monkeys in this study are given in Table 1 . The leucocytes of some individuals reacted with antisera for three alleles for one locus. In these cases all three alleles are given for the individuals. Two infants reacted with none of the antisera for alleles at the second locus. On the basis of these tests males could be eliminated as possible fathers of infants, since each individual possesses a pair of alleles at each locus, one allele from each parent. For example, Ae's infant $\mathrm{Rg}$ has alleles 1 and 9 for PHI while Ae has only 1 ; $\mathrm{Rg}$ received allele 9 from her father. The males which possess this allele are $\mathrm{Gd}, \mathrm{Ob}$ and $\mathrm{Se}$ (see Table 1).

Table 1. The biochemical evidence from which paternity could be deduced in a group of rhesus monkeys for (a) 1972 or (b) 1973

\begin{tabular}{|c|c|c|c|c|c|c|c|c|}
\hline & \multirow[b]{2}{*}{ 6PGD } & \multirow[b]{2}{*}{ PHI } & \multirow[b]{2}{*}{ CA II } & \multirow[b]{2}{*}{ Transferrin } & \multirow{2}{*}{$\begin{array}{c}\text { NADH } \\
\text { diaphorase }\end{array}$} & \multicolumn{2}{|c|}{ Leucocyte antigens } & \multirow{2}{*}{$\begin{array}{l}\text { Putative } \\
\text { fathers }\end{array}$} \\
\hline & & & & & & 1 & 2 & \\
\hline \multicolumn{9}{|c|}{ Males } \\
\hline $\mathrm{Ce}$ & $\mathbf{A} \mathbf{A}$ & 11 & A B & F D & C D & $65^{*}$ & $11^{*} 11^{*}$ & \\
\hline Gd & $\mathbf{A} \mathbf{A}$ & 19 & B $\mathbf{B}$ & F D & $\mathrm{C} \mathrm{C}$ & 69 & $202^{*}$ & \\
\hline $\mathrm{Kd}$ & A A & 11 & B B & F F & D D & - & - & \\
\hline $\mathrm{Ob}$ & A B & 19 & A B & H F & C D & 99 & $11^{*} 11^{*}$ & \\
\hline $\mathrm{Pe}$ & $\mathbf{A} \mathbf{A}$ & 11 & A B & E A & $\mathrm{C} \mathbf{C}$ & $5^{*} r_{1} 10$ & $1411 * 2 *$ & \\
\hline Qe & A B & 11 & B $\mathbf{B}$ & F B & D D & 66 & $11^{*}$ r18 13 & \\
\hline $\operatorname{Re}$ & $\mathbf{A} \mathbf{A}$ & 11 & $\mathbf{A} \mathbf{A}$ & F F & $\mathrm{C} \mathrm{C}$ & $10 R_{1} R_{3}$ & $11 * 11 *$ & \\
\hline $\mathrm{Se}$ & A A & 19 & B B & E B & C D & $9 \times 19$ & $11^{*} 2^{*}$ & \\
\hline
\end{tabular}

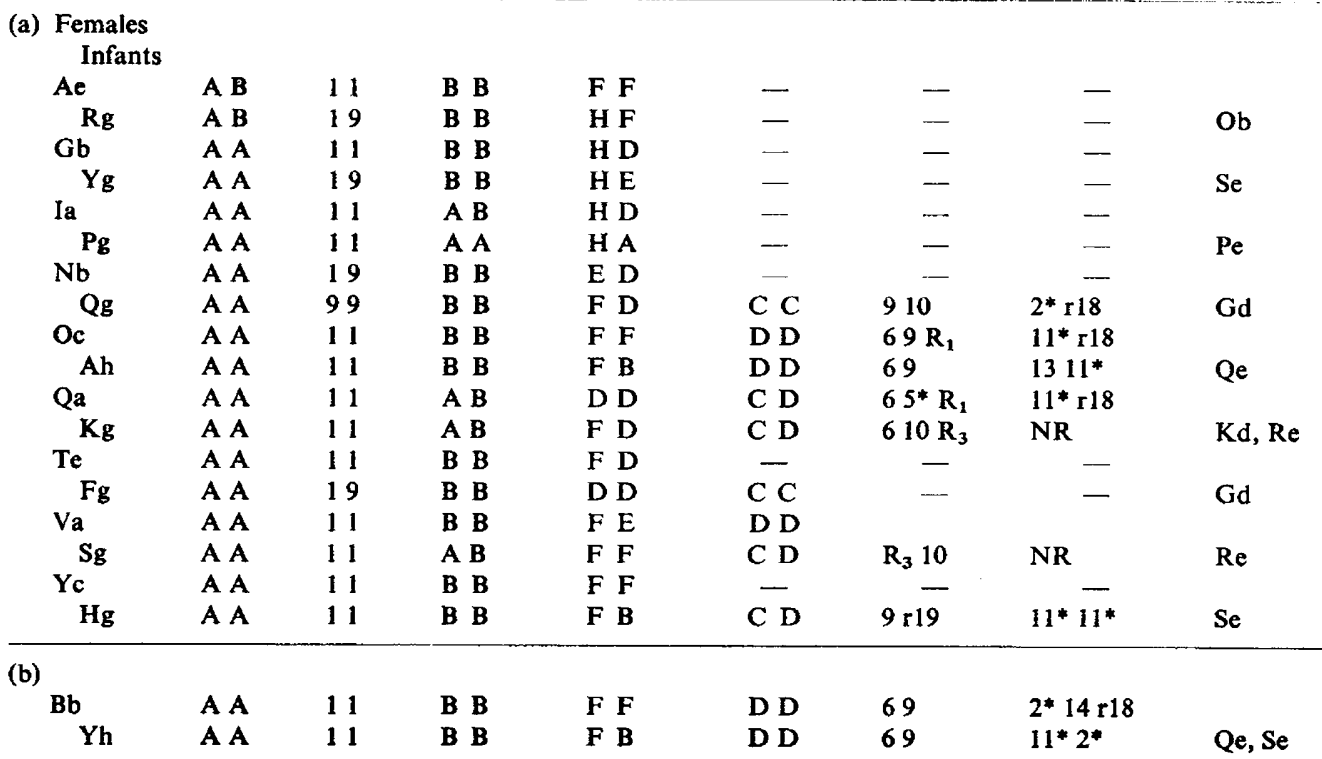


Table 1-continued

\begin{tabular}{|c|c|c|c|c|c|c|c|c|}
\hline & \multirow[b]{2}{*}{ 6PGD } & \multirow[b]{2}{*}{ PHI } & \multirow[b]{2}{*}{ CA II } & \multirow[b]{2}{*}{ Transferrin } & \multirow{2}{*}{$\begin{array}{c}\text { NADH } \\
\text { diaphorase }\end{array}$} & \multicolumn{2}{|c|}{ Leucocyte antigens } & \multirow{2}{*}{$\begin{array}{l}\text { Putative } \\
\text { fathers }\end{array}$} \\
\hline & & & & & & 1 & 2 & \\
\hline $\mathrm{Bd}$ & A B & 11 & A B & F F & C C & $10 R_{3} r 19$ & $\mathrm{r} 1711^{*} 2^{*}$ & \\
\hline $\mathbf{P h}$ & $\mathbf{A} \mathbf{A}$ & 11 & A B & F F & $\mathrm{C} \mathrm{C}$ & $10 R_{2} r 19$ & r17 $11 * 2 *$ & $\mathbf{R e}$ \\
\hline $\mathbf{F b}$ & $\mathbf{A} \mathbf{A}$ & 11 & A B & F F & - & ¿ & - & \\
\hline $\mathrm{Ci}$ & $\mathbf{A} \mathbf{A}$ & 11 & B B & $\mathbf{F} \mathbf{D}$ & C C & 99 & $2 * \mathrm{r} 17$ & Gd \\
\hline Gf & $\mathbf{A} \mathbf{A}$ & 11 & A B & $\mathbf{F} \mathbf{F}$ & - & - & - & \\
\hline Di & $\mathbf{A} \mathbf{A}$ & 19 & A B & F B & - & - & - & $\mathrm{Se}$ \\
\hline $\mathbf{J b}$ & A A & 11 & B B & F F & C D & $95^{*}$ & $\mathrm{r} 1711 * \mathrm{r} 18$ & \\
\hline $\mathrm{Kh}$ & A A & 11 & B $\mathbf{B}$ & F D & $\mathrm{C} \mathrm{C}$ & 69 & $11 *$ r20 & Gd \\
\hline $\mathrm{Nb}$ & A A & 19 & B B & E D & - & - & - & \\
\hline $\mathbf{Q h}$ & $\mathbf{A} \mathbf{A}$ & 19 & $\mathbf{A} \mathbf{B}$ & F E & C C & $10 R_{1}$ & $11 * 11 *$ & $\mathbf{R e}$ \\
\hline $\mathrm{Oa}$ & A A & 11 & $\mathbf{A} \mathbf{A}$ & F E & C E & 910 & $2 * 14$ & \\
\hline $\mathbf{R h}$ & $\mathbf{A} \mathbf{A}$ & 11 & A B & F F & C C & $910 R_{1}$ & $11 * 2 * 14$ & $\mathbf{R e}$ \\
\hline Oc & A A & 11 & B B & F F & D D & $69 R_{1}$ & $11 * \mathrm{r} 18$ & \\
\hline $\mathrm{Nh}$ & $\mathbf{A} \mathbf{A}$ & 11 & B $\mathbf{B}$ & F B & D D & $9 r 19$ & $11^{*} 2^{*}$ & $\mathrm{Se}$ \\
\hline Od & $\mathbf{A} \mathbf{A}$ & 11 & $\mathbf{A} \mathbf{A}$ & F B & - & - & - & \\
\hline Ih & A A & 19 & A B & F $\mathbf{B}$ & $\mathrm{CC}$ & 99 & $2 * 2^{*}$ & $\mathrm{Gd}, \mathrm{Se}$ \\
\hline Qd & A B & 11 & A B & F B & - & - & - & \\
\hline Lh & $\mathbf{A} \mathbf{A}$ & 11 & A B & E B & C C & 69 & $11 * \mathrm{r} 18$ & Se \\
\hline $\mathbf{R a}$ & $\mathbf{A} \mathbf{A}$ & 19 & B B & F $\mathbf{B}$ & - & - & $\longrightarrow$ & \\
\hline Th & A A & 99 & B B & F F & - & - & - & $\mathrm{Se}$ \\
\hline $\mathbf{S b}$ & $\mathbf{A} \mathbf{A}$ & 11 & B $\mathbf{B}$ & F F & - & - & - & \\
\hline Jh & A A & 11 & A B & $\mathbf{F A}$ & - & - & 一 & $\mathrm{Pe}$ \\
\hline Td & A A & 11 & B B & F D & - & - & - & \\
\hline $\mathrm{Fi}$ & A A & 19 & B B & D D & - & - & - & Gd \\
\hline Ub & $\mathbf{A} \mathbf{A}$ & 11 & B B & F F & - & - & - & \\
\hline Wh & A A & 11 & B B & $\mathbf{F A}$ & - & - & - & $\mathrm{Pe}$ \\
\hline $\mathrm{Ue}$ & $\mathbf{A} \mathbf{A}$ & 11 & B B & F F & - & - & - & \\
\hline $\mathbf{V h}$ & $\mathbf{A} \mathbf{A}$ & 19 & B $\mathbf{B}$ & F B & - & 69 & $11 *$ r18 & $\mathrm{Se}$ \\
\hline Va & $\mathbf{A} \mathbf{A}$ & 11 & B B & F E & D D & - & - & \\
\hline $\mathbf{B i}$ & $\mathbf{A} \mathbf{A}$ & 19 & B B & F D & - & - & - & Gd \\
\hline $\mathrm{Vc}$ & A A & 11 & B B & F B & D D & $105^{*} R_{1}$ & $11 * \mathrm{r} 17$ & \\
\hline $\mathrm{Gi}$ & A A & 11 & A B & F F & $\mathrm{CD}$ & $5^{*} \mathbf{R}_{3}$ & $11 *$ r17 & Re \\
\hline $\mathrm{Ve}$ & $\mathbf{A} \mathbf{A}$ & 11 & A B & F D & - & - & - & \\
\hline $\mathrm{Mh}$ & $A \mathrm{~A}$ & 19 & B B & F E & - & - & - & Se \\
\hline $\mathbf{W c}$ & $\mathbf{A} \mathbf{A}$ & 11 & B B & F B & C D & $105^{*}$ & $\mathrm{r} 1713$ & \\
\hline Oh & $\mathbf{A} \mathbf{A}$ & 11 & A B & F F & $C D$ & $105^{*}$ & $11 * \mathrm{r} 17$ & $\mathrm{Re}, \mathrm{Ce}$ \\
\hline Yd & $\mathbf{A} \mathbf{A}$ & 11 & A B & $F D$ & - & - & - & \\
\hline $\mathbf{Z h}$ & A B & 11 & B B & H D & - & - & - & $\mathrm{Ob}$ \\
\hline
\end{tabular}

Gd has been the alpha male since the formation of the initial group in 1970, and he maintained this position until his death in 1974. In October 1971 at the beginning of the breeding season male $\mathrm{Gd}$ was the highest in rank, followed by $\mathrm{Kd}$ and $\mathrm{Ob}$ of middle rank, with $\mathrm{Ce}, \mathrm{Re}, \mathrm{Qe}, \mathrm{Se}$ and $\mathrm{Pe}$ of low rank in order of their relative agonistic dominance. At the end of the 1971 breeding season (January 1972), the order was Gd (high), Re (middle-high), $\mathrm{Kd}$ and $\mathrm{Ob}$ (middle) and $\mathrm{Ce}, \mathrm{Se}, \mathrm{Pe}$ and $\mathrm{Qe}$ (low). In the breeding season of 1972 the order was Gd and Re (high), Se and Pe (middle) and $\mathrm{Qe}, \mathrm{Ce}, \mathrm{Ob}$ and $\mathrm{Kd}$ (low).

\section{Discussion}

When the basic group was formed in the spring of 1970 , dominance ranks were stable with male Gd as the alpha animal; $\mathrm{Kd}$ was an old male, and $\mathrm{Ob}$ was a young male, probably not sexually mature. The same methods as those described in this paper were used to determine paternity for infants produced during the first year. Male Gd apparently fathered all of the infants, but he may have been the only fertile male in the group since $\mathrm{Kd}$ has never proved to be the father of any infant and $\mathrm{Ob}$ is believed to have been sexually immature at that time. In the spring of 1971, additional animals 
were added by merger with a smaller group containing four adult males and one male (Ce) became sexually mature. The newly added animals, including the males ( $\mathrm{Re}, \mathrm{Qe}, \mathrm{Se}, \mathrm{Pe}$ ), took the lowest ranks after their defeat (Bernstein, Gordon \& Rose, 1974) and stayed so in the breeding season of 1971. The subsequent changes in rank reflect their integration into the troop, a process possibly aided by their association with high-ranking females during the breeding season (T. P. Gordon, unpublished). During the first breeding season after the merger (1971), all the newly integrated males fathered offspring. Males Se, and possibly $\mathrm{Re}$, fathered as many as $\mathrm{Gd}$, the alpha male.

Male $\mathrm{Ob}$, an adolescent male in 1971 and 1972, and of only middle rank and low rank during those years, nonetheless fathered infants in both years, suggesting that even low-ranking adolescent males may be reproductively effective in a troop and obviously do have access to at least some females at ovulation.

During the two seasons, the alpha male, Gd, could have produced no more than 7 out of 29 of the offspring. Thus we can reject the hypothesis that the alpha male fathers all or even most $(P<0.01)$ of the infants in a group.

It is still possible, however, that the alpha male produces a disproportionately larger number of offspring than other males and that the number of offspring relates to the relative rank of the males. Since there were 8 breeding males, male Gd would have to have fathered 8 offspring to have produced a significantly larger number of young than would be expected by chance $(P<0.02)$. In fact, male Gd definitely fathered 6 infants but could not have produced more than 7. Male Se, of lower rank, has both more known $(8)(P<0.02)$ and more possible (10 out of $29 ; P<0.002)$ offspring than does male Gd. Thus male Se fathered more infants than any other male in the group despite the fact that he was of low rank one year and only of middle rank the next.

Table 2. Comparison of reproductive ability and dominance of rhesus monkey males

\begin{tabular}{|c|c|c|c|c|c|c|}
\hline \multirow[b]{2}{*}{ Male } & \multicolumn{3}{|c|}{1972} & \multicolumn{3}{|c|}{1973} \\
\hline & $\begin{array}{l}\text { Known } \\
\text { infants }\end{array}$ & $\begin{array}{c}\text { Possible } \\
\text { infants }\end{array}$ & Total & $\begin{array}{l}\text { Known } \\
\text { infants }\end{array}$ & $\begin{array}{c}\text { Possible } \\
\text { infants }\end{array}$ & Total \\
\hline $\mathrm{Ce}$ & 0 & 0 & 0 & 0 & 2 & 2 \\
\hline Gd & 2 & 0 & 2 & 4 & 1 & 5 \\
\hline $\mathrm{Kd}$ & 0 & 1 & 1 & 0 & 0 & 0 \\
\hline Ob & 1 & 0 & 1 & 1 & 0 & 1 \\
\hline $\mathrm{Pe}$ & 1 & 0 & 1 & 2 & 0 & 2 \\
\hline $\mathrm{Qe}$ & 1 & 0 & 1 & 0 & 1 & 1 \\
\hline $\mathrm{Re}$ & 1 & 1 & 2 & 4 & 1 & 5 \\
\hline $\mathrm{Se}$ & 2 & 0 & 2 & 6 & 2 & 8 \\
\hline
\end{tabular}

Correiation (Spearman's test) with ranks:

October 1971, known young, $\rho=0.231$, N.S.; total young, $\rho=0 \cdot 276$, N.S.

January, 1972, known young, $\rho=0.505$, N.S.; total young, $\rho=0 \cdot 570$, N.S.

November 1972, known young, $\rho=0.805, P<0.02$; total young, $\rho=0.890, P<0.01$.

The reproductive records of all the males were compared to their relative ranks and the results for each year w'ere independently tested to see if the number of offspring correlated with the relative ranks (Table 2). The correlations were not significant for 1972 but were for 1973, indicating that we cannot reject the null hypothesis that reproductive success is independent of rank $\left(H_{0}: r=0 \cdot 0\right)$ for 1972 but that this hypothesis may be rejected for 1973 . We therefore conclude that: (1) the alpha male in this group does not do all the mating, or even most of the successful mating, and (2) evidence exists to demonstrate increased genetic fitness for males in this group as a function of relative agonistic rank for the second but not the first of the 2 years in this study.

It appears, therefore, that dominance in rhesus monkeys need not always directly relate to breeding success and that the genetic fitness of an animal obtaining the alpha position may not lie in his ability to produce the largest numbers of offspring during his years of dominance. Bernstein (1976) has argued that the increased genetic fitness of alpha males may lie in their ability to increase the probability of survival for their offspring, rather than their increased reproductive activity. Primates 
in general enhance genetic fitness by maximizing the survival of those young which they do produce. They are long-lived, and while physical abilities may not reach full potential for several years, and may wane with age, reproductive success in any one year is not necessarily indicative of lifetime reproductive performance. If genetic fitness is enhanced in males who achieve high rank at some point in their life, it must therefore be a resultant of lifetime reproductive success, rather than production of many infants only during their years as alpha male.

The recent work of Drickamer \& Vessey (1973) suggests that rank among males in free-ranging rhesus groups is largely a function of age and seniority. High rank is therefore related to those characteristics which enhance a male's ability to remain in a troop long enough to achieve seniority. High-ranking males with seniority in a troop have thus contributed to breeding over the largest number of years. The alpha male and other high-ranking males are therefore in a position to be protecting a population of infants to which they have already made the largest genetic contribution.

This research was supported by grants MH13864, MH20483, MH58049-01 and in part by RR00165.

\section{References}

Barnicot, N.A. \& Cohen, P. (1970) Red cell enzymes of primates (Anthropoidea). Biochem. Genet. 4, 41-57.

Barnicot, N.A. \& Hewett-Emmitt, D. (1971) Red cell and serum proteins of talapoin, patas and vervet monkeys. Folia primatol. 15, 65-76.

Bernstein, I.S. (1970) Primate status hierarchies. In Primate Behavior (Developments in Field and Laboratory Research), vol. 1, pp. 71-109. Ed. L. A. Rosenblum. Academic Press, New York.

Bernstein, I.S. (1976) Dominance, aggression and reproduction in primate societies. $J$. theoret. Biol. (in press).

Bernstein, I.S., Gordon, T.P. \& Rose, R.M. (1974) Aggression and social controls in rhesus monkey (Macaca mulatta) groups revealed in group formation studies. Folia primatol. 21, 81-107.

Carpenter, C.R. (1942) Sexual behavior of freeranging rhesus (Macaca mulatta). II. Periodicity of estrus, homosexual, autoerotic and non-conformist behavior. J. comp. Physiol. 33, 147-162.

Conaway, C.H. \& Koford, C.B. (1965) Estrous cycles and mating behavior in a free-ranging band of rhesus monkeys. J. Mammal. 45, 577-587.

DRiCKAMER, L.C. (1974) Social rank, observability, and sexual behaviour of rhesus monkeys (Macaca mulatta). J. Reprod. Fert. 37, 117-120.

Drickamer, L.C. \& VeSSEY, S.H. (1973) Group changing in free-ranging male rhesus monkeys. Primates 14, 359-368.

EAton, G.G. \& Resko, J.A. (1974) Plasma testosterone and male dominance in a Japanese macaque (Macaca fuscata) troop compared with repeated measures of testosterone in laboratory males. Horm. \& Behav. 5, 251-259.

Fildes, R.A. \& Harris, H. (1966) Genetically determined variation of adenylate kinase in man. Nature, Lond. 209, 261-263.

Fildes, R.A. \& PARR, C.W. (1963) Human red cell phosphogluconate dehydrogenase. Nature, Lond. $200,890$.
Gartlan, S. (1968) Structure and function in primate society. Folia primatol. 8, 89-120.

GibletT, E.R. (1969) Genetic Markers in Human Blood. R. A. Davis \& Co., Philadelphia.

Gordon, T.P., Rose, R.M. \& Bernsten, I.S. (1976) Seasonal rhythm in plasma testosterone levels in the rhesus monkey (Macaca mulatta): a three year study. Horm. \& Behav. (in press).

Goss-Custard, J.D., Dunbar, R.I.M. \& AldrichBlake, F.P.G. (1972) Survival, mating and rearing strategies in the evolution of primate social structure. Folia primatol. 17, 1-19.

HALl, K.R.L. \& DEVoRe, I. (1965) Baboon social behavior. In Primate Behavior. Field Studies of Monkeys and Apes, pp. 53-110. Ed. I. DeVore. Holt, Rinehart and Winston, New York.

Jsнімото, G. (1971) Electrophoretic patterns of red cell NADH diaphorase in macaque monkeys. J. anthrop. Soc. Japan 29, 382-387.

Ishimoto, G. \& Kuwata, M. (1972) Phosphohexose isomerase polymorphism in macaques. Jap. J. human Genet. 16, 154-165.

KAUfMAN, J.H. (1965) A 3-year study of mating behaviour in a free-ranging band of rhesus monkeys. Ecology 46, 500-512.

KAUfMaN, J.H. (1967) Social relations of adult males in a free-ranging band of rhesus monkeys. In Social Communication among Primates, pp. 73-98. Ed. S. A. Altmann. University of Chicago Press.

Keverne, E.B. \& Michael, R.P. (1971) Sex attractant properties of ether extracts of vag inal secretions from rhesus monkeys. J. Endocr. 51, 313-322.

KoFORD, C.B. (1963) Rank of mothers and sons in bands of rhesus monkeys. Science, N.Y. 141, 356-357.

LoY, J. (1971) Estrous behavior of free-ranging rhesus monkeys (Macaca mulatta). Primates 12, 1-31.

Poulik, M.D. (1957) Starch gel electrophoresis in a discontinuous system of buffers. Nature, Lond. 180, 1477-1479.

Prochodko, W., Goodman, M., Singal, B.H., Weiss, M.L., Ishimoto, G. \& TANAKA, R. (1972) Starch-gel 
electrophoretic variants of erythrocyte 6-phosphogluconate dehydrogenase in Asian macaques. Primates 12, 175-182.

SADE, D. (1968) Inhibition of son-mother mating among free-ranging monkeys. Sci. Psychoanal. 12, 18-37.

Simonds, P.E. (1974) The Social Primates. Harper and Row, New York.

Smithies, O. (1959) Zone electrophoresis in starch gels and its application to studies of serum proteins. Adv. Prot. Chem. 14, 65.

SPencer, N., Hopkinson, S.A. \& HARris, H. (1964)
Phosphoglucomutase polymorphism in man. Nature, Lond. 204, 742-745.

TASHIAN, R.E. (1965) Genetic variation and evolution of the carboxylic esterases and carbonic anhydrases of primate erythrocytes. Am. J. hum. Genet. 17, 257-272.

Tashian, R.E., Goodman, M., Headings, V.E., DESIMONE, J. \& WARD, J.H. (1971) Genetic variation and evolution in the red cell carbonic anhydrase isozymes of macaque monkeys. Biochem. Genet. 5 , 183-200.

Received 14 July 1975 